University of Nebraska - Lincoln

DigitalCommons@University of Nebraska - Lincoln

Faculty Papers and Publications in Animal

Science

Animal Science Department

February 1983

\title{
THE EFFECTS OF LEVEL OF CRUDE PROTEIN ON PERFORMANCE OF GROWING BOARS
}

\author{
R. W. Tyler \\ Oklahoma State University, Stillwater \\ W. G. Luce \\ Oklahoma State University, Stillwater \\ R. K. Johnson \\ Oklahoma State University, Stillwater, rjohnson5@unl.edu \\ C. V. Maxwell \\ Oklahoma State University, Stillwater \\ R. L. Hintz \\ Oklahoma State University, Stillwater \\ See next page for additional authors
}

Follow this and additional works at: https://digitalcommons.unl.edu/animalscifacpub

Part of the Animal Sciences Commons

Tyler, R. W.; Luce, W. G.; Johnson, R. K.; Maxwell, C. V.; Hintz, R. L.; and Walters, L. E., "THE EFFECTS OF LEVEL OF CRUDE PROTEIN ON PERFORMANCE OF GROWING BOARS" (1983). Faculty Papers and Publications in Animal Science. 34.

https://digitalcommons.unl.edu/animalscifacpub/34

This Article is brought to you for free and open access by the Animal Science Department at DigitalCommons@University of Nebraska - Lincoln. It has been accepted for inclusion in Faculty Papers and Publications in Animal Science by an authorized administrator of DigitalCommons@University of Nebraska - Lincoln. 


\section{Authors}

R. W. Tyler, W. G. Luce, R. K. Johnson, C. V. Maxwell, R. L. Hintz, and L. E. Walters 


\title{
THE EFFECTS OF LEVEL OF CRUDE PROTEIN ON PERFORMANCE OF GROWING BOARS ${ }^{1}$
}

\author{
R. W. Tyler ${ }^{2}$, W. G. Luce, R. K. Johnson ${ }^{3}$ C. V. Maxwell, \\ R. L. Hintz and L. E. Walters \\ Oklahoma State University ${ }^{4}$, Stillwater 74078
}

\section{Summary}

Five trials involving 432 growing boars were utilized to study the effects of six levels of crude protein on gain, feed efficiency, feed intake, backfat thickness and longissimus muscle area. The boars were fed ad libitum either a $14,16,18,20,22$ or $24 \%$ crude protein diet from about 24.6 to $54.4 \mathrm{~kg}$ (period 1). From 54.4 to $98.8 \mathrm{~kg}$ (period 2), the crude protein in each diet was reduced by $2 \%$. During period 1, gain increased and feed to gain ratio decreased quadratically $(P<.05)$ with increasing dietary crude protein in corn-soybean meal based diets and were maximum at protein levels of 20 to $22 \%$. Feed intake was not affected by dietary protein level. During period 2, protein level did not significantly affect rate of gain, feed efficieney or feed intake. Overall, gain increased quadratically $(P<.05)$ with increasing protein levels and was maximum for boars fed the $20 / 18 \%$ protein sequence during periods 1 and 2 , respectively. Feed to gain ratio decreased linearly $(\mathrm{P}<.05)$ with increasing dietary protein intake. Feed intake was not affected by dietary protein level. Scan backfat thickness and longissimus muscle area obtained at the end of the trial indicated that backfat decreased linearly $(\mathrm{P}<.05)$ with increasing protein intake, while longissimus muscle area increased quadratically $(\mathrm{P}<.05)$ as protein in the diet increased. These results indicate that small improvements in average daily gain, feed efficiency, longissimus

\footnotetext{
${ }^{1}$ Oklahoma Agr. Exp. Sta. Journal Article No. 4116.

${ }^{2}$ Current address: Quachita County Agent, Camden, AR 71701.

${ }^{3}$ Current address: Anim. Sci. Dept., Univ. of Nebraska, Lincoln.

${ }^{4}$ Dept. of Anim. Sci.

Received June 24, 1982.

Accepted January 7, 1983.
}

muscle area and backfat thickness can be made by feeding protein levels to growing boars approximately $2 \%$ higher than the currently recommended $18 \%$ protein diet during the growing period $(24.6$ to $58.4 \mathrm{~kg}$ ), followed by an $18 \%$ diet during the finishing period (54.8 to $98.8 \mathrm{~kg}$ ).

(Key Words: Protein Levels, Growing Boars.)

\section{Introduction}

Information concerning the effect of protein level on performance and carcass characteristics in the growing boar is somewhat limited and the results of studies to date are inconsistent. Although it has become an accepted industry practice to feed a higher level of protein to growing boars than to barrows and gilts, some studies in the literature have failed to show an effect of sex or castration on protein requirement (Wong et al., 1968; Pay and Davies, 1973) or amino acid requirement (Hines et al., 1975). However, Creswell et al. (1975) found that low protein intake depressed gain more in boars than in barrows, but observed similar responses in both groups for carcass characteristics. Bayley and Summers (1968) observed that boars responded to increased protein level with increased gain and decreased feed to gain ratio, whereas gilts did not.

Speer et al. (1957) observed a quadratic response in gain to dietary protein as protein level increased from 13 to $25 \%$ crude protein in boars fed corn-soybean meal-animal protein based diets. Similarly, Reinhard et al. (1976) using corn-soybean meal based diets, observed a curvilinear response in gain and feed:gain ( $F: G)$ ratio in growing boars fed dietary protein levels from 14 to $22 \%$, and Traverner et al. (1977), using wheat-soybean meal-meat and bone meal based diets, observed a curvilinear increase in gain of boars fed protein levels between 14 and $23 \%$. Luce et al. (1976), using corn-soybean meal based diets, reported a linear increase in gain 364

JOURNAL OF ANIMAL SCIENCE, Vol. 57, No. 2, 1983 
and a quadratic decrease in $F: G$ ratio as percentage dietary protein increased from 16 to $20 \%$ in the growing period and 14 to $18 \%$ in the finishing period. But Wong et al. (1968) observed no effect of protein on gain or feed efficiency in boars fed barley-soybean meal diets containing either 17 or $13 \%$ protein from 50 to $88.6 \mathrm{~kg}$ and Pay and Davies (1973) observed a decrease in gain and efficiency of gain as protein levels increased from 16 to $20 \%$ in boars fed diets containing a combination of animal and plant protein sources from 55 to 90 $\mathrm{kg}$.

The objective of this study was to determine the effect of a wide range of protein levels on growth rate, average daily feed intake, feed efficiency and estimated carcass traits of boars.

\section{Experimental Procedure}

Five trials with a total of 432 Duroc, Hampshire, Yorkshire and Duroc $\times$ Hampshire boars were utilized as the complete data base for this study, although the mean performance of boars in trials 1 and 2 has been published earlier (Luce et al., 1976). In trials 1,2 and 3, 108 boars were allotted to three treatments; 54 boars were allotted to three treatments during trials 4 and 5. Protein levels fed from about 24.6 to $54.4 \mathrm{~kg}$ were as follows: trials 1 and $2,16,18$ or $20 \%$; trial $3,14,16$ or $18 \%$; trial $4,18,20$ or $22 \%$ and trial $5,20,22$ or $24 \%$. From about 54.4 to $98.8 \mathrm{~kg}$ the protein level of each diet was reduced $2 \%$. The composition of the corn-soybean meal-based diets is shown in table 1. Protein levels in the diet were reduced for each pen individually as the boars in the pen averaged $54.4 \mathrm{~kg}$ and boars were individually removed from test weekly as they reached 100 $\mathrm{kg}$. Ultrasonic estimates of backfat thickness and longissimus muscle area were obtained as described by Luce et al. (1976).

The boars were allotted to treatments as they reached $8 \mathrm{wk}$ of age. The allotment on any day included 27 boars (nine/pen) with an equal number from each breed group. A maximum of three breed groups were represented in each trial. Assignment to pens was done randomly within breed and litter. A group of boars assigned to treatments on $1 \mathrm{~d}$ constituted one block of each trial. Trials 1,2 and 3 contained four blocks each and trials 4 and 5 each contained two blocks.

Methods of data collection, management and facilities were the same for each individual trial and have been defined by Luce et al. (1976).

Each trial was conducted independently and was analyzed separately. With pens as the experimental unit, the design of each trial was a randomized block. The analysis utilized a model that included the effects of blocks, treatments and error (blocks $x$ treatments). The linear and quadratic components of protein treatment mean squares were tested for significance by use of the F-test.

Data from all trials were combined and subjected to regression analyses to evaluate the effect of dietary protein on the response variables. The five trials were combined to form an incomplete block design and analysis of the response was preformed using the Statistical Analysis System general linear model (GLM) procedure (SAS, 1979).

The initial model partitioned the variation into sources shown in table 2 . Trial $x$ treatment interaction was not significant for any of the growth responses and allowed further modification of the model. The final model considered those sources of variation due to trial, replications within trial and treatment (table 3). Treatment effects were partitioned into linear and quadratic components.

Next, two regression analyses were computed, one with the linear effect of treatments and the other with linear and quadratic treatment effects. When a quadratic response was probable $(P<.25)$, the analysis that included the quadratic effect was used.

All traits measured were plotted against level of protein when a significant linear or quadratic treatment effect was observed. The response graph for each trait shows the average change in the dependent variable for each unit $(2 \%)$ change in level of protein.

\section{Results and Discussion}

The means of performance of boars on each treatment in trials 1 and 2 have been published earlier (Luce et al., 1976). Tabular results for trials 3, 4 and 5 are shown in tables 4,5 and 6 , respectively.

Trial 3. In trial 3 (table 4), increasing protein level from 14 to $18 \%$ in boars from 21.8 to $56.4 \mathrm{~kg}$ caused a linear increase $(P<.01)$ in average daily gain (ADG) and tended to improve $F: G$ ratio. Average daily feed intake (ADFI) was not significantly affected by dietary protein level. From 56.4 to $96.2 \mathrm{~kg}$, ADG tended to increase (linear effect, $P<.10$ ) as 
TYLER ET AL.

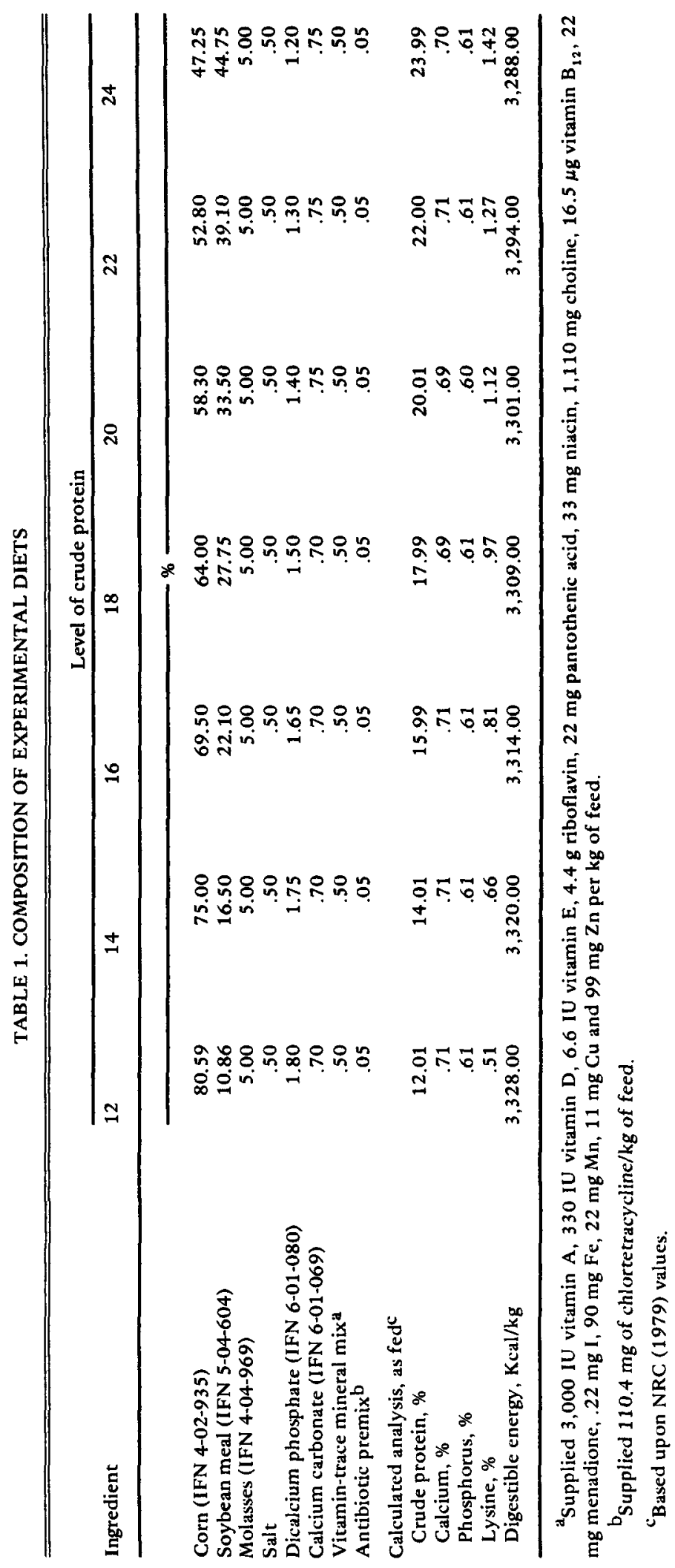


TABLE 2. PRIMARY ANALYSIS OF VARIANCE FOR DATA COMBINED FROM ALL TRIALS

\begin{tabular}{lr}
\hline Source of variation & $\mathrm{df}$ \\
\hline Regression & 25 \\
Trial & 5 \\
Rep. within trial & 11 \\
Treatment & 5 \\
Linear & 1 \\
Quadratic & 1 \\
Residual & 3 \\
Trial $X$ treatment & 5 \\
Linear $X$ trial & 4 \\
Quadratic $X$ trial & 1 \\
Error & 22 \\
Corrected total & 47 \\
\hline
\end{tabular}

dietary protein was increased from 12 to $16 \%$, but $F: G$ ratio was unaffected. Pigs fed the $14 \%$ diet consumed less feed than those consuming either the 12 or $16 \%$ protein diets (quadratic effect, $P<.10$ ).

Longissimus muscle area, measured at the end of the trial, indicated that dietary protein level had an effect on muscle development. Longissimus muscle area increased linearly $(\mathrm{P}<.05)$ with increasing dietary protein. $\mathrm{Al}-$ though the linear component was significant, the actual longissimus muscle area was highest in pigs fed the intermediate protein level (quadratic effect, $P<.10$ ). Scan backfat thickness was not affected by dietary treatment in this trial.

Trial 4. In trial 4 (table 5), increasing protein levels from 18 to $22 \%$ in boars from 30.7 to $54.7 \mathrm{~kg}$ had no effect on ADG, but F:G ratio

TABLE 3. FINAL MODELS USED FOR ANALYSIS OF DATA COMBINED FROM ALL TRIALS ${ }^{\mathrm{a}}$ DEPENDING ON QUADRATIC OR LINEAR EFFECTS

\begin{tabular}{lrlr}
\hline Source of variation & df & Source of variation & df \\
\hline Regression & 16 & Regression & 17 \\
$\quad$ Trial & 4 & Trial & 4 \\
Rep. within trial & 11 & Rep. within trial & 11 \\
Linear & 1 & Linear & 1 \\
& & Quadratic & 1 \\
Error & 31 & Error & 30 \\
Corrected total & 47 & Corrected total & 47 \\
\hline
\end{tabular}

${ }^{\mathrm{a}}$ Quadratic effects were deleted if $\mathrm{P}>.25$. tended to decrease quadratically $(P<.10)$. There was also a trend for lower feed intake for boars fed the intermediate protein level than for those fed either higher or lower dietary protein levels (quadratic effect, $P<.10$ ). From 54.7 to $97.8 \mathrm{~kg}$, ADG decreased quadratically $(\mathrm{P}<.05)$ as dietary protein level increased from 16 to $20 \%$. Feed to gain ratio and ADFI were not significantly affected by dietary protein level. For the entire feeding period ( 30.7 to $97.8 \mathrm{~kg}$ ), neither ADG, $F: G$ ratio nor ADFI were significantly affected by dietary protein level. Scan backfat thickness measured at the end of the trial decreased linearly $(\mathrm{P}<.01)$ with increasing protein intake, whereas scan longissimus muscle area was not affected by dietary protein level.

Trial 5. In trial 5 (table 6), ADG, F:G ratio and ADFI from 27 to $54.7 \mathrm{~kg}$ were similar for boars fed 20 to $24 \%$ protein diets. However, for boars fed 18 to $22 \%$ protein diets from 54.7 to $94.1 \mathrm{~kg}$, ADG decreased quadratically $(\mathrm{P}<.05)$ with increasing protein level. Neither $F: G$ ratio nor ADFI was affected by dietary protein level in this feeding period. For the overall feeding period (27 to $94.1 \mathrm{~kg}$ ), ADG, $F: G$ ratio and ADFI were not affected by dietary protein level. Scan backfat tended to decrease with increasing protein intake, although differences were not significant. As observed in trials 1,2 and 3 , scan longissimus muscle area was affected by dietary protein intake. However, unlike the response in the earlier trials in which longissimus muscle area increased with increasing dietary protein at lower dietary protein levels, longissimus muscle area tended to decrease linearly $(\mathrm{P}<.10)$ as protein level increased from the $20 / 18$ to the $24 / 22 \%$ sequence.

\section{Combined Trials}

Results of the combined regression analyses are shown in figures 1 through 6. Graphic representations of responses are illustrated only in cases in which an effect $(\mathrm{P}<.05)$ of protein level was observed over all trials.

Gain. Average daily gain of boars from 24.6 to $54.4 \mathrm{~kg}$ (period 1) increased with increasing dietary protein level from 14 to $20 \%$ of the diet, followed by a decline in gain at higher protein levels (figure 1; quadratic effect, $\mathrm{P}<.01$ ). The level of protein required to achieve maximum gain calculated from the regression equation was $20.9 \%$. This is consistent with the observation in trials 1 and 2 that increasing 
TABLE 4. EFFECTS OF LEVEL OF CRUDE PROTEIN ON PERFORMANCE OF GROWING BOARS (TRIAL 3)

\begin{tabular}{|c|c|c|c|c|}
\hline \multirow[b]{2}{*}{ Item } & \multicolumn{3}{|c|}{ Protein level, \% } & \multirow[b]{2}{*}{ SE } \\
\hline & 14 to $12^{a}$ & 16 to 14 & 18 to 16 & \\
\hline \multicolumn{5}{|l|}{ Avg daily gain, $\mathrm{kg}$} \\
\hline 21.8 to $56.4 \mathrm{~kg}^{\mathrm{b}}$ & .60 & .70 & .73 & .02 \\
\hline 56.4 to $96.2 \mathrm{kgc}^{\mathrm{c}}$ & .86 & .85 & .94 & .04 \\
\hline 21.8 to $96.2 \mathrm{kgb}$ & .69 & .76 & .84 & .02 \\
\hline \multicolumn{5}{|l|}{ Feed/kg gain, $\mathrm{kg}$} \\
\hline 21.8 to $56.4 \mathrm{kgc}^{\mathrm{c}}$ & 2.83 & 2.64 & 2.48 & .11 \\
\hline 56.4 to $96.2 \mathrm{~kg}$ & 3.26 & 3.35 & 3.06 & .22 \\
\hline 21.8 to $96.2 \mathrm{~kg}$ & 3.00 & 2.87 & 2.81 & .11 \\
\hline \multicolumn{5}{|l|}{ Avg daily feed intake, $\mathrm{kg}$} \\
\hline 21.8 to $56.4 \mathrm{~kg}$ & 1.70 & 1.86 & 1.81 & .06 \\
\hline 56.4 to $96.2 \mathrm{kgd}$ & 2.72 & 2.24 & 2.96 & .24 \\
\hline 21.8 to $96.2 \mathrm{~kg}$ & 2.09 & 2.03 & 2.39 & .13 \\
\hline Scan backfat thickness, $\mathrm{cm}$ & 2.77 & 2.54 & 2.60 & .08 \\
\hline Scan longissimus muslce area, $\mathrm{cm}^{2}$ de & $32: 64$ & 34.72 & 34.37 & .55 \\
\hline
\end{tabular}

${ }^{a}$ Each treatment consisted of four pens of nine boars.

$b_{\text {Linear effect }(P<.01)}$.

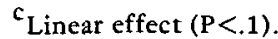

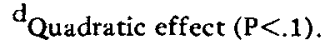

e Linear effect $(P<.05)$.

TABLE 5. EFFECTS OF LEVEL OF CRUDE PROTEIN ON PERFORMANCE OF GROWING BOARS (TRIAL 4)

\begin{tabular}{|c|c|c|c|c|}
\hline \multirow[b]{2}{*}{ Item } & \multicolumn{3}{|c|}{ Protein levels, \% } & \multirow[b]{2}{*}{$\mathrm{SE}$} \\
\hline & 18 to $16^{a}$ & 20 to 18 & 22 to 20 & \\
\hline \multicolumn{5}{|l|}{ Avg daily gain, kg } \\
\hline 30.7 to $54.7 \mathrm{~kg}$ & .73 & .76 & .75 & .02 \\
\hline 54.7 to $97.8 \mathrm{kgb}$ & .93 & .79 & .84 & .04 \\
\hline 30.7 to $97.8 \mathrm{~kg}$ & .85 & .78 & .80 & .02 \\
\hline \multicolumn{5}{|l|}{ Feed/kg gain, kg } \\
\hline 30.7 to $54.7 \mathrm{kgc}$ & 2.48 & 2.18 & 2.36 & .07 \\
\hline 54.7 to $97.8 \mathrm{~kg}$ & 2.92 & 3.02 & 2.86 & .05 \\
\hline 30.7 to $97.8 \mathrm{~kg}$ & 2.78 & 2.69 & 2.68 & .04 \\
\hline \multicolumn{5}{|l|}{ Avg daily feed intake, $\mathrm{kg}$} \\
\hline 30.7 to $54.7 \mathrm{kgc}$ & 1.81 & 1.67 & 1.77 & .03 \\
\hline 54.7 to $97.8 \mathrm{~kg}$ & 2.60 & 2.35 & 2.59 & .19 \\
\hline 30.7 to $97.8 \mathrm{~kg}$ & 2.28 & 2.04 & 2.22 & .10 \\
\hline Scan backfat thickness, $\mathrm{cm} d$ & 2.48 & 2.26 & 2.16 & .09 \\
\hline Scan longissimus muscle area, $\mathrm{cm}^{2}$ & 35.54 & 36.04 & 35.08 & .78 \\
\hline
\end{tabular}

\footnotetext{
${ }^{a}$ Each treatment consisted of two pens of nine boars.

${ }^{b}$ Quadratic effect $(P<.05)$.

${ }^{\complement}$ Quadratic effect $(P<.10)$.

$d_{\text {Linear effect }}(P<.05)$.
} 
TABLE 6. EFFECTS OF LEVEL OF CRUDE PROTEIN ON PERFORMANCE OF GROWING BOARS (TRIAL 5)

\begin{tabular}{|c|c|c|c|c|}
\hline \multirow[b]{2}{*}{ Item } & \multicolumn{3}{|c|}{ Protein level, \% } & \multirow[b]{2}{*}{ SE } \\
\hline & 20 to $18^{a}$ & 22 to 20 & 24 to 22 & \\
\hline $\begin{array}{l}\text { Avg daily gain, } \mathrm{kg} \\
27 \text { to } 54.7 \mathrm{~kg} \\
54.7 \text { to } 94.1 \mathrm{kgb} \\
27 \text { to } 94.1 \mathrm{~kg}\end{array}$ & $\begin{array}{l}.75 \\
.79 \\
.77\end{array}$ & $\begin{array}{l}.78 \\
.67 \\
.71\end{array}$ & $\begin{array}{l}.75 \\
.74 \\
.74\end{array}$ & $\begin{array}{l}.03 \\
.04 \\
.02\end{array}$ \\
\hline $\begin{array}{l}\text { Feed } / \mathrm{kg} \text { gain, } \mathrm{kg} \\
27 \text { to } 54.7 \mathrm{~kg} \\
54.7 \text { to } 94.1 \mathrm{~kg} \\
27 \text { to } 94.1 \mathrm{~kg}\end{array}$ & $\begin{array}{l}2.27 \\
3.06 \\
2.76\end{array}$ & $\begin{array}{l}2.22 \\
3.44 \\
2.79\end{array}$ & $\begin{array}{l}2.32 \\
3.05 \\
2.77\end{array}$ & $\begin{array}{l}.04 \\
.12 \\
.10\end{array}$ \\
\hline $\begin{array}{l}\text { Avg daily feed intake, } \mathrm{kg} \\
27 \text { to } 54.7 \mathrm{~kg} \\
54.7 \text { to } 94.1 \mathrm{~kg} \\
27 \text { to } 94.1 \mathrm{~kg}\end{array}$ & $\begin{array}{l}1.70 \\
2.51 \\
2.20\end{array}$ & $\begin{array}{l}1.72 \\
2.68 \\
2.31\end{array}$ & $\begin{array}{l}1.71 \\
2.36 \\
2.10\end{array}$ & $\begin{array}{l}.06 \\
.39 \\
.22\end{array}$ \\
\hline $\begin{array}{l}\text { Scan backfat thickness, } \mathrm{cm} \\
\text { Scan longissimus muscle area, } \mathrm{cm}^{2} \mathrm{c}\end{array}$ & $\begin{array}{r}2.37 \\
33.52\end{array}$ & $\begin{array}{r}2.36 \\
32.24\end{array}$ & $\begin{array}{r}2.29 \\
31.50\end{array}$ & $\begin{array}{l}.11 \\
.75\end{array}$ \\
\hline
\end{tabular}

${ }^{a}$ Each treatment consisted of two pens of nine boars.

${ }^{b}$ Quadratic effect $(P<.05)$.

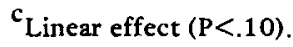

protein levels for the growing boar from low to moderate levels $(16$ to $20 \%)$ linearly $(\mathrm{P}<.01)$ increased rate of gain (Luce et al., 1976) and the observation in trial 3 that increasing protein levels from 14 to $18 \%$ resulted in a linear increase in gain $(P<.01)$. But increasing protein from moderate to high levels of 18 to $22 \%$ in trial 4 and 20 to $24 \%$ in trial 5 had no effect on gain.

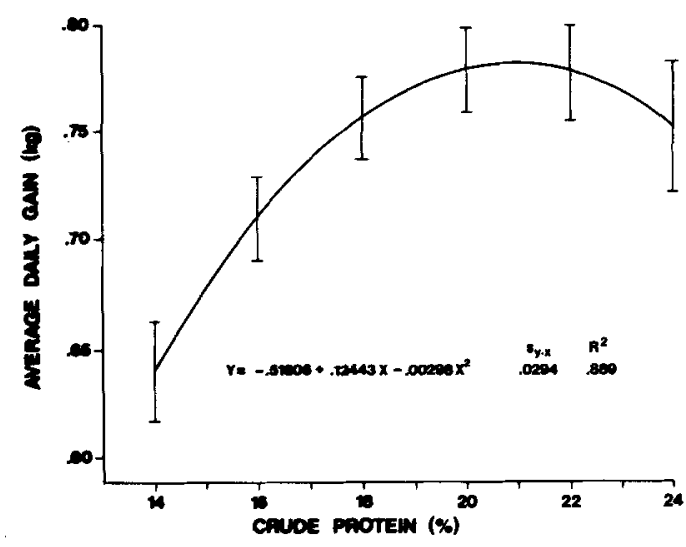

Figure 1. The effect of dietary protein level on average daily gain in boars from 24.6 to $54.4 \mathrm{~kg}$. Vertical lines represent $95 \%$ confidence limits for the means.
Gain of boars during period 2 (54.4 to 98.8 $\mathrm{kg}$ ) was not affected by dietary protein level. It should be noted, however, that ADG of boars increased linearly $(\mathrm{P}<.05)$ as protein levels increased from 14 to $18 \%$ in trials 1 and 2 (Luce et al., 1976) and tended to increase linearly $(\mathrm{P}<.10)$ in trial 3 as protein level increased from 12 to $16 \%$. A quadratic decrease in gain with increasing dietary protein level was observed in trials 4 and 5 as protein levels were increased from 16 to $20 \%(\mathrm{P}<.05)$ and from 18 to $22 \% \quad(\mathrm{P}<.10)$, respectively, suggesting a similar trend in gain with protein intake in period 2 as that observed during period 1 .

As would be expected from the results of the two periods, ADG over the entire feeding period (24.6 to $98.8 \mathrm{~kg}$ ) increased quadratically $(\mathrm{P}<.05$; figure 2$)$ with increasing protein. Average daily gain increased as protein levels were increased from the $14 / 12$ to the $20 / 18 \%$ sequence and began to decline at higher levels of protein intake. The level of crude protein required for maximum gain over the entire feeding period calculated from the regression equation was the $20 / 18 \%$ sequence.

Maximum gains were attained at protein levels about $4 \%$ above the currently recommended protein levels for growing barrows and gilts (NRC, 1979) and about $2 \%$ above the 


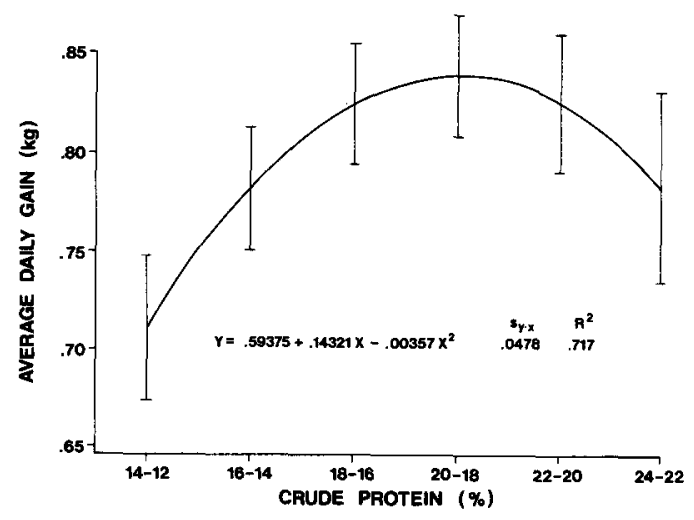

Figure 2. The effect of dietary protein level on average daily gain in boars from 24.6 to $98.8 \mathrm{~kg}$. Vertical lines represent $95 \%$ confidence limits for the means.

recommended protein levels for growing boars (Hubbard, 1981). The protein level required for maximum gain in growing boars (24.6 to 54.4 $\mathrm{kg}$ ) is similar to the $19.6 \%$ reported by Traverner et al. (1977) for growing boars fed a wheat-soybean meal based diet from 20 to $70 \mathrm{~kg}$ in a once daily feeding regimen. Similar responses in increased gain with increasing protein intake for growing boars have been reported by Speer et al. (1957), Pay and Davies (1973), Creswell et al. (1975) and Reinhard et al. (1976). As was observed in this study, the effect of protein level on gain in boars in the finishing phase has been less consistent. Pay and Davies (1973) observed a decrease in ADG of boars from 55 to $90 \mathrm{~kg}$ as protein level increased from 16 to $20 \%$. Wong et al. (1968) observed similar gains for boars fed either a 12 or $17 \%$ protein diet from 50 to $88.6 \mathrm{~kg}$.

The depression in growth rate exhibited by boars fed the diets with highest protein levels was due to either the lower energy content of the diets (table 1) or to the higher protein intake, because there was no effect of protein level on ADFI in the combined analysis. In the one trial (trial 4) in which the effect of protein level on ADFI resulted in a quadratic trend $(\mathrm{P}<.10)$, the actual ADFI was lower for boars fed the intermediate protein level than either the higher or lower protein levels. Similar curvilinear responses in ADG of growing boars to increasing levels of dietary protein have been reported (Reinhard et al., 1976; Traverner et al., 1977). In addition, Speer et al. (1957) reported that gains of boars improved as the protein level was increased from 13 to $19 \%$ and then decreased at higher protein levels.

Feed to Gain Ratio. Feed to gain ratio from 21.6 to $54.4 \mathrm{~kg}$ (period 1) improved as dietary protein level increased from $14 \%$, reached a plateau at 20 or $22 \%$ protein and declined for boars fed the $24 \%$ protein diet (figure 3; quadratic effect, $\mathrm{P}<.01$ ). This is consistent with the observation in trials 1,2 and 3 in which increasing protein from low to moderate levels improved feed to gain ratio, whereas at higher protein levels, a trend toward a decreasing rate of improvement in F:G ratio was observed in trial 4 and no effect of dietary protein level on $F: G$ ratio was observed in trial 5 . These data suggest that $F: G$ ratio from 24.6 to $54.4 \mathrm{~kg}$ is maximized at a protein level of $20 \%$, although the rate of improvement in $\mathrm{F}: \mathrm{G}$ ratio is minimal in boars fed protein levels above $18 \%$. Reinhard et al. (1976) observed an improvement in F:G ratio in growing boars ( 20 to $55 \mathrm{~kg}$ ) fed protein levels from 14 to $18 \%$, followed by a decline in feed efficiency at either 20 or $22 \%$ protein. Traverner et al. (1977) indicated that F:G ratio was improved in growing boars (20 to $70 \mathrm{~kg}$ ) with protein levels up to $19.3 \%$, followed by a depressed efficiency of gain at higher protein levels. The level of crude protein required for minimum $F$ : $G$ ratio in our study was $21.1 \%$.

During period 2 (54 to $98.8 \mathrm{~kg}$ ), the effect of protein on $\mathrm{F}: \mathrm{G}$ ratio was inconsistent among the individual trials and the overall effect was nonsignificant in the combined regression

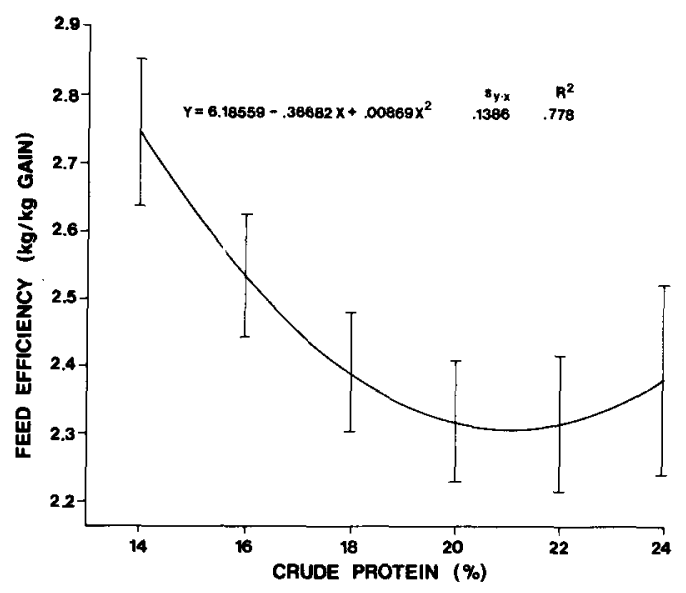

Figure 3. The effect of dietary protein level on feed to gain ratio in boars from 24.6 to $54.4 \mathrm{~kg}$. Vertical lines represent $95 \%$ confidence limits for the means. 
analysis. In trials 1 and 2 (Luce et al., 1976), $F: G$ ratio tended to decrease quadratically $(\mathrm{P}<.10)$ as percentage of protein in the diet increased from 14 to $18 \%$. Increasing protein level from 12 to $16 \%$ in trial 3 and from 16 to $20 \%$ and 18 to $22 \%$ in trials 4 and 5 , respectively, had no effect on $F: G$ ratio of boars during period 2. It should be noted, however, that data from trials 1 and 2 (Luce et al., 1976) suggest little improvement in $F: G$ ratio at protein levels above $16 \%$. This response is in agreement with that of Pay and Davies (1973), who observed a decrease in efficiency of gain of boars $(55$ to $90 \mathrm{~kg}$ ) fed protein levels from 16 to $20 \%$. Wong et al. (1968) found no difference in feed efficiency between boars fed either a 13 or $17 \%$ protein diet from 50 to $88.6 \mathrm{~kg}$.

Feed to gain ratio over the entire feeding period (25.6 to $98.8 \mathrm{~kg}$ ) decreased linearly (figure $4 ; \mathrm{P}<.05$ ) with increasing dietary protein level. This linear decrease in $F: G$ ratio in the combined analysis is in contrast to the quadratic $(\mathrm{P}<.01)$ decrease observed in period 1 and to the quadratic decrease in $F: G$ ratio observed in periods 1,2 and for the entire feeding period in trials 1 and 2 (Luce et al., 1976). In trials 3,4 and $5, F: G$ ratio over the entire feeding period was not affected by dietary protein level. Pay and Davies (1973) found no effect of protein on $F: G$ ratio from 22 to $90 \mathrm{~kg}$ for boars fed protein levels from 16 to $20 \%$.

Carcass Traits. Scan backfat and longissimus muscle area measured at the end of the trial indicated a dramatic change in estimates of leanness as dietary protein increased. Backfat

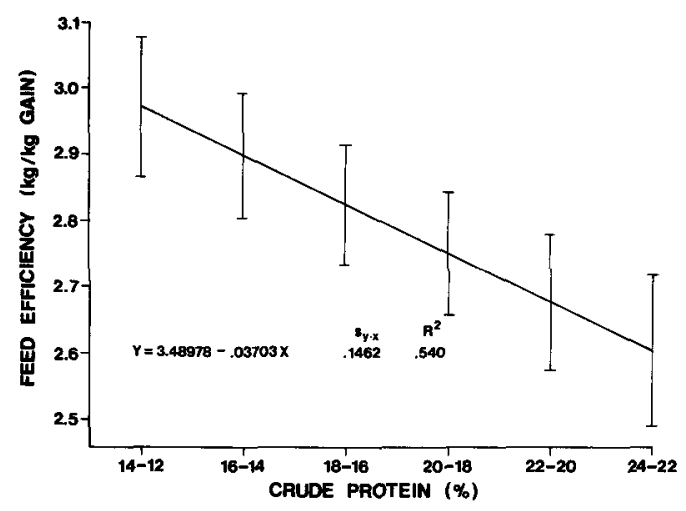

Figure 4 . The effect of dietary protein level on feed to gain ratio from 24.6 to $98.8 \mathrm{~kg}$. Vertical lines represent $95 \%$ confidence limits for the means. decreased linearly (figure $5 ; \mathrm{P}<.05$ ) as protein level increased from a $14 / 12$ to a $24 / 22 \%$ protein feeding sequence. Longissimus muscle area increased from a low for boars fed the $14 / 12 \%$ protein sequence, reached a plateau in boars fed either the $18 / 16$ to the $20 / 18 \%$ protein sequence and declined in boars fed higher levels of protein (figure 6; quadratic effect $P<.05)$. The level of crude protein required for maximum longissimus muscle area in our study was $19.1 \%$.

A similar response of decreased backfat in boars fed higher levels of protein has been reported by Speer et al. (1957). Numerous studies with barrows and gilts have shown that increasing dietary protein level decreases backfat (Hale et al., 1967; Lee et al., 1967; NcBee et al., 1969; Tjong-A-Hung et al., 1972, Gilster and Wahlstrom, 1973). Pay and Davies (1973) observed a similar fat depth in boars fed protein levels from 16 to $20 \%$, whereas Reinhard et al. (1976) observed a curvilinear response in backfat thickness in boars fed protein levels from 14 to $22 \%$.

The curvilinear response in longissimus muscle area is similar to the finding of other researchers using other methods to estimate carcass muscling. Traverner et al. (1977) observed a curvilinear response to dietary protein and lean content of the ham, with boars requiring $21 \%$ protein to maximize ham leanness, and Reinhard et al. (1976) observed a curvilinear response in percentage lean cuts to increasing dietary protein level. Boars required an $18 \%$ protein diet to maximize percentage lean cuts. Pay and Davies (1973), however, observed similar longissimus muscle areas in boars fed protein levels from 16 to $20 \%$. The

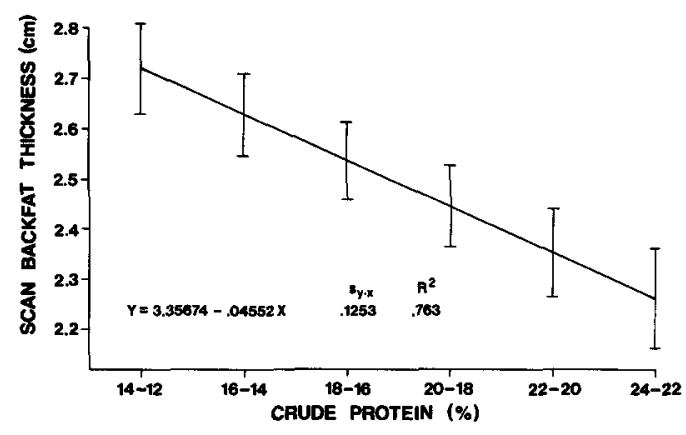

Figure 5. The effect of protein level on scan backfat thickness. Vertical lines represent $95 \%$ confidence limits for the means. 


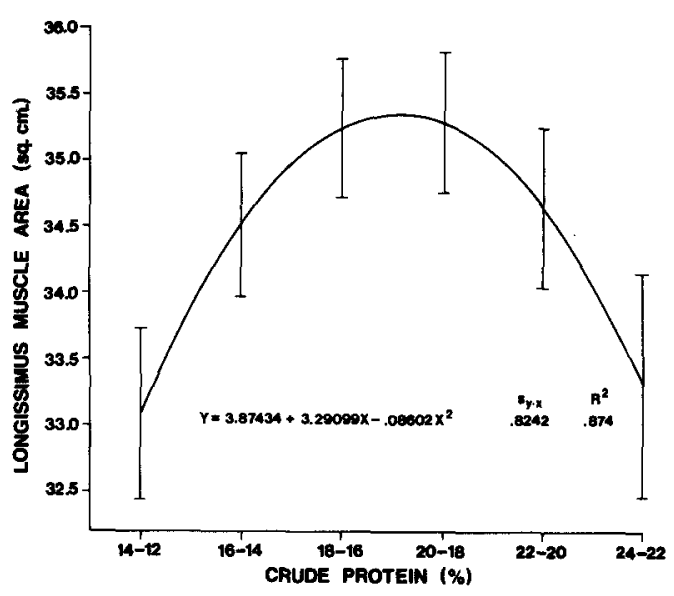

Figure 6. The effect of protein level on scan longissimus muscle area. Vertical lines represent $95 \%$ confidence limits for the means.

tendency for a quadratic response of muscling to increasing dietary protein indicates that maximum muscle gain is attained at protein levels from 18 to $20 \%$, whereas most studies indicate that the level of protein that maximizes leanness may be higher. Because weight gain also appears to decrease at higher protein levels, leanness may simply reflect the reduction in gain, and feeding boars to maximize gain and efficiency of gain would appear to be more critical than feeding a diet to maximize leanness.

\section{Literature Cited}

Bayley, H. S. and J. D. Summers. 1968. Effect of protein level and lysine and methionine supplementation on the performance of growing pigs; response of different sexes and strains of pigs. Can. J. Anim. Sci. 48:181.

Creswell, D. C., H. D. Wallace, G. E. Combs, A. Z. Palmer and R. L. West. 1975. Lysine and tryptophan in diets for boars and barrows. J. Anim. Sci. 40:167 (Abstr.).

Gilster, K. E. and R. C. Wahlstrom. 1973. Protein levels for swine fed to heavy weights. II. Effects on quantitative and qualitative carcass characteristics. J. Anim. Sci. 36:888.
Hale, O. M., J. D. Johnson, Jr. and B. L. Southwell. 1967. Influence of dietary protein on performance and carcass traits of swine. Univ. of Georgia Res. Bull. 13.

Hines, R. H., K. C. Ferrell, G. L. Alee and B. A. Koch. 1975. The effect of sex and lysine requirement of finishing pigs. J. Anim. Sci. 41:316 (Abstr.).

Hubbard, D. D. 1981. Guidelines for uniform swine improvement programs. USDA Sci. and Ed. Adm. Program Aid 1157.

Lee, C., J. L. McBee, Jr. and D. J. Horvath. 1967. Dietary protein level and swine carcass traits. J. Anim. Sci. 26:490.

Luce, W. G., R. K. Johnson and L. E. Walters. 1976. Effects of levels of crude protein on performance of growing boars. J. Anim. Sci. 42:1207.

McBee, J. L., Jr., D. J. Horvath, C. Lee and C. W. Scherer. 1969. Relationship of dietary protein level to carcass characteristics and growth performance of swine. West Virginia Univ. Agr. Exp. Sta. Bull. 576T.

NRC. 1979. Nutrient Requirements of Domestic Animals, No. 2. Nutrient Requirements of Swine. Eighth Revised Ed. National academy of Sciences-National Research Council, Washington, DC.

Pay, M. G. and T. E. Davis. 1973. Growth, food conversion, and carcass characteristics in castrated and entire male pigs fed three different dietary protein levels. J. Agr. Sci. (Camb.) 81:65.

Reinhard, M. K., D. C. Mahan, B. L. Workman, J. H. Cline, A. W. Fetter and A. P. Grito, Jr. 1976. Effect of increasing dietary protein level, calcium and phosphorus on feedlot performance, bone mineralization and serum mineral values with growing swine. J. Anim. Sci. 43:770.

SAS. 1979. SAS User's Guide. Statistical Analysis System Institute, Cary, NC.

Speer, V. C., E. L. Lasley, G. C. Ashton, L. N. Hazel and D. V. Catron. 1957. Protein levels for growing boars on pasture and concrete drylot. J. Anim. Sci. 16:607.

Tjong-A-Hung, A. R., L. E. Hanson, J. W. Rust and R. J. Meade. 1972. Effects of protein level sequence and sex on rate and efficiency of gain of growing swine and on carcass characteristics, including composition of lean tissue. J. Anim. Sci. 35:760.

Traverner, M. R., R. G. Campbell and R. H. King. 1977. The relative protein and energy requirements of boars, gilts and barrows. Australian J. Exp. Agr. Anim. Husb. 17:574.

Wong, W. C., W. J. Boylan and S. C. Stothers. 1968. Effects of dietary protein level and sex on swine performance and carcass traits. Can. J. Anim. Sci. $48: 383$. 